\title{
Mandibular Range Movement in Pediatric Patients
}

\author{
Rango de Movimiento Mandibular en Pacientes Pediátricos
}

\author{
Veronica Iturriaga ${ }^{1,2}$; Thomas Bornhardt'; Alain Arias ${ }^{3,4}$; Marvid Antiao ${ }^{5}$; \\ Yanela Aravena ${ }^{5}$; Pablo Navarro ${ }^{1,3}$ \& Carlos Manterola ${ }^{6,7}$
}

ITURRIAGA, V.; BORNHARDT, T.; ARIAS, A.; ANTIAO, M.; ARAVENA, Y.; NAVARRO, P. \& MANTEROLA, C. Mandibular range movement in pediatric patients. Int. J. Odontostomat., 11(1):83-87, 2017.

ABSTRACT: Assessing the normal range of manibular movement becomes an indispensable tool for the clinical evaluation of the function of the masticatory system. The aim of this study was to measure the range of mandibular movement in mouth opening, protrusion, and lateral movements in pediatric subjects from the city of Temuco, Chile and to determine their association with age, sex, and height. A cross-sectional study was performed in children aged 6-13, treated in the Teaching-Unit-Dental-Clinic at the Universidad de La Frontera, Temuco-Chile. 54 subjects participated in the study (44.4 \% females); girls exhibited an average mouth opening of $51.9 \mathrm{~mm}$ and males of $54.8 \mathrm{~mm}$. Averages were $53.5 \mathrm{~mm}$ for mouth opening, $11.8 \mathrm{~mm}$ for protrusion, $9.9 \mathrm{~mm}$ for right laterality, and $10.3 \mathrm{~mm}$ for left laterality. A statistically significant difference was found between age groups, opening, and right lateral ranges, as well as a weak to moderate correlation between mouth opening and protrusion, protrusion and right laterality, protrusion and left laterality, right and left laterality, height and mouth opening, and height and right lateral ranges. The results of this study provide specific data and evidence on the importance of evaluating all ranges of mandibular movement, relating them to each other and with variables such as age and height.

KEY WORDS: mandibular dynamics, temporomandibular joint, temporomandibular joint disorders, mandibular range, children.

\section{INTRODUCTION}

Mandibular movements or mandibular dynamics (MD) are defined as the movements that the jaw performs in different planes of space, by combination of condylar translation and rotation movements (Manns, 2011). When moving upward or downward, both condyles rotate simultaneously against their joint disks while these move down and forward, or up and backwards, following the back slope and crest of the joint eminence. In protrusive and retrusive movements, the events are similar except that condylar translation movements are dominant over condylar rotation. Finally, right and left lateral movements are asymmetric due to the fact that temporomandibular joints (TMJs) can move independently (Manns). The evaluation of ranges of $M D$ is a valuable, simple, and objective parameter for the clinical assessment of TMJ function, chewing muscles, and adjoining structures (Hirsch et al., 2006; Cortese et al., 2007; Sousa et al., 2008), allowing us to assign a value to each movement and to identify possible structural alterations.

The objective of this study was to measure ranges of $\mathrm{MD}$ in mouth opening, protrusion, and lateral movements in pediatric subjects from the city of Temuco, Chile and to determine their association with age, sex, and height. This study was written according to the STROBE statement guidelines for reporting observational studies (Von Elm et al., 2008).

\footnotetext{
${ }^{1}$ Departamento de Odontología Integral del Adulto, Universidad de La Frontera, Temuco, Chile.

2 Programa Doctorado en Ciencias Médicas, Universidad de La Frontera, Temuco, Chile. Becario CONICYT, PFCHA/ Doctorado Nacional/ 2015-21151352.

${ }^{3}$ Centro de Investigación en Ciencias Odontológicas (CICO), Facultad de Odontología, Universidad de La Frontera, Temuco, Chile.

${ }^{4}$ Programa de Magíster en Odontología, Facultad de Odontiología, Universidad de La Frontera, Temuco, Chile.

${ }^{5}$ Private practice.

${ }^{6}$ Departamento de Cirugía y CEMyQ, Universidad de La Frontera, Temuco, Chile.

${ }^{7}$ Centro de Investigaciones Biomédicas, Universidad Autónoma de Chile.
} 


\section{MATERIALS AND METHOD}

Study design and Center: Across-sectional study was conducted. The study was performed at the Teaching Unit Dental Clinic at the Universidad de La Frontera, Temuco, Chile. It was carried out during patient care in the evenings, in the period from May to August 2014.

Participants: All patients between the ages of 6-13 that agreed to participate in the study were included, signing the informed consent/assent form. Subjects that were not able to follow instructions, those with braces, with both permanent central incisors partially erupted, and those that used prostheses were excluded.

Result variables: We evaluated mouth opening, protrusion, right lateral, left lateral, age, sex, and height ranges of the subjects. The ranges of motion functioned as a continuous variable and were measured inmillimeters using a caliper. To determine range of mouth opening movement, the distance from the incisal edge of the upper central incisor to the incisal edge of the lower central incisor was measured with the patient in a position of maximum un-assisted mouth opening, adding vertical incisor overbite in a position of maximum intercuspation. Protrusion movement was evaluated by asking the patient to perform a maximum protrusion without tooth contact, and the distance between the vestibular surface of the right upper central incisor and the vestibular surface of the bottom right central incisor was measured, adding horizontal incisor overbite. Lateral ranges were measured by creating a vertical line that passed through the upper right central incisor and the lower right central incisor. Then, the patient was asked to perform a maximum lateral movement without tooth contact. The resulting distance between the top and bottom line was recorded; the right side was measured first, followed by the left side. When right central incisors were not present, were partially erupted, or were distant from the average arc with respect to the anterior teeth, we measured their left counterpart.

The age variable functions as a continuous and categorical variable, establishing 4 age groups for every two years: group 1 (aged 6-7 years), group 2 (aged 8 to 9 years), group 3 (aged 10-11 years), and group 4 (aged 12-13 years). The sex variable was determined by directly consulting the patient and was considered dichotomously (male, female). Height funtions as a continuous variable and was measured in $\mathrm{cm}$ using measuring tape.
Bias: Actions were taken to prevent measurement bias, always using the same instrument when measuring patient ranges of motion. In addition, the researchers responsible for recording the variables calibrated them with a specialist in temporomandibular disorders and orofacial pain, obtaining a kappa coefficient greater than 0.8 .

Sample size: Non-probability sampling was used for convenience.

Statistical methods: Inferential and descriptive statistics (mean $\pm S D$ ) were performed. Being a quantitative analysis, a one-way ANOVA test, Bonferroni multiple comparisons test, Pearson correlation coefficient, and t-test were used for independent samples. The Pearson Chi-square test was conducted for the qualitative variables. The data were analyzed using SPSS/PC software version 20.0, SPSS, Chicago, IL; a value of $p<0.05$ was chosen as the threshold for significance.

Ethical aspects: The study was accepted by the Scientific Ethics Committee at the Universidad de La Frontera (Exempt Resolution No. 4204).

\section{RESULTS}

From a total of 54 subjects, the average age was $9.6 \pm 1.6$ years, and $44.4 \%$ corresponded to females; there were no statistically significant differences between these variables $(p=0.113)$. Averages were $53.5 \pm 6.1$ for mouth opening, $11.8 \pm 3.4$ for protrusion, $9.9 \pm 2.6$ for right lateral, and 10.3 \pm 2.8 for left lateral movement; no significant differences were found according to sex (Table I). A significant increase in mandibular opening range was observed as patient age increased $(p=0.010)$; significant differences were specifically found between patients aged 6-7 and those aged 12-13 ( $p=0.005)$. A similar trend was also exhibited with right lateral range and the different age groups ( $p=0.003$ ); differences were specifically found between the sub-groups of 6-7 years old and 12-13 years old $(p=0.038)$ (Table II).

On the other hand, a weak to moderate direct correlation was observed between ranges of mouth opening and protrusion $(r=0.298)$; between ranges of 
protrusion and of the right side $(r=0.337)$; between protrusion and the left side $(r=0.395)$; and between the right and left sides ( $r=0.435)$; all of these are statistically significant. Similarly, a moderate direct correlation was found between height and mouth opening ( $r=0.370)$ and with the right side ( $r=0.312)$; both are statistically significant. The results from the different correlations are detailed in Table III.

Table I. Mandibular movement ranges according to patient sex.

\begin{tabular}{lcccc}
\hline & Male & Female & Total & $p$-value \\
\hline Mouth opening $(\mathrm{mm})$ & 54.8 & 51.9 & 53.5 & 0.080 \\
Protrusion $(\mathrm{mm})$ & 12.1 & 11.5 & 11.8 & 0.544 \\
Right side $(\mathrm{mm})$ & 10.2 & 9.8 & 9.9 & 0.559 \\
Left side $(\mathrm{mm})$ & 10.6 & 9.8 & 10.3 & 0.323
\end{tabular}

* distribution significantly different according to patient sex, p-value $<0.05$

Table II. Mandibular movement ranges according to patient age groups.

\begin{tabular}{lcccc}
\hline & $\begin{array}{c}\text { Opening } \\
(\mathrm{mm})\end{array}$ & $\begin{array}{c}\text { Protrusion } \\
(\mathrm{mm})\end{array}$ & Right side $(\mathrm{mm})$ & $\begin{array}{c}\text { Left side } \\
(\mathrm{mm})\end{array}$ \\
\hline Aged 6-7 & $46.4 \pm 2.5$ & $10.4 \pm 2.7$ & $8.4 \pm 1.9$ & $7.8 \pm 2.2$ \\
Aged 8-9 & $53.3 \pm 5.9$ & $11.3 \pm 2.8$ & $9.1 \pm 2.2$ & $10.0 \pm 3.0$ \\
Aged 10-11 & $53.9(5.88)$ & $11.9 \pm 3.4$ & $10.7 \pm 2.3$ & $10.9 \pm 2.6$ \\
Aged 12-13 & $58.0 \pm 5.6$ & $12.4 \pm 3.2$ & $11.4 \pm 3.5$ & $10.9 \pm 2.5$ \\
Total & $53.5 \pm 6.2$ & $11.8 \pm 3.4$ & $9.9 \pm 2.6$ & $10.3 \pm 2.8$ \\
p-value & $0.011^{*}$ & 0.649 & $0.031^{*}$ & 0.146 \\
\hline
\end{tabular}

* distribution significantly different according to age groups, $p$-value $<0.05$

Table III. Correlation between variables of height, mouth opening, mandibular protrusion, right side and left side.

\begin{tabular}{|c|c|c|c|c|c|c|}
\hline & & $\begin{array}{c}\text { Heigh } \\
t\end{array}$ & $\begin{array}{c}\text { Mouth } \\
\text { opening }\end{array}$ & Protrusion & Right side & Left side \\
\hline \multirow[t]{2}{*}{ Height } & Pearson correlation & 1 & $0.370^{* \star}$ & 0.099 & $0.312^{*}$ & 0.134 \\
\hline & Sig. (bilateral) & & 0.006 & 0.475 & 0.022 & 0.333 \\
\hline \multirow[t]{2}{*}{ Mouth opening } & Pearson correlation & & 1 & $0.298^{*}$ & 0.205 & 0.255 \\
\hline & Sig. (bilateral) & & & 0.029 & 0.138 & 0.063 \\
\hline \multirow[t]{2}{*}{ Protrusion } & Pearson correlation & & 0.298 & 1 & 0.337 & 0.395 \\
\hline & Sig. (bilateral) & & 0.029 & & 0.013 & 0.003 \\
\hline \multirow[t]{2}{*}{ Right side } & Pearson correlation & & 0.205 & $0.337^{*}$ & 1 & $0.435^{\pi \pi}$ \\
\hline & Sig. (bilateral) & & 0.138 & 0.013 & & 0.001 \\
\hline \multirow[t]{2}{*}{ Left side } & Pearson correlation & & 0.255 & 0.395 & 0.435 & \\
\hline & Sig. (bilateral) & & 0.063 & 0.003 & 0.001 & 1 \\
\hline
\end{tabular}

* The correlation is significant at the 0.05 level (bilateral). ${ }^{* *}$ The correlation is significant at the 0.01 level (bilateral).

\section{DISCUSSION}

Assessing mandibular movement is considered an important clinical tool for evaluating the state of TMJs and their associated structures, where a decrease or increase in the values of these ranges can be associated with an alteration (Bonjardim et al., 2004; Sousa et al., 2008; Abou-Atme et al., 2008; Kumar et al., 2012). Numerous studies use the range of mandibular opening for such purposes. However, it has been reported that this movement may vary depending on age, sex, and anthropometric factors such as height, weight, race, mandibular size, and cranial base size (Casanova-Rosado et al., 2012).

There are no similar studies in the Chilean population. However, a study conducted in Brazil with 65 children aged between 3 and 5 showed an average 
value of $41.4 \mathrm{~mm}$ for maximum opening for boys and $39.9 \mathrm{~mm}$ for girls (Bonjardim et al.). In Argentina, the average was $41.9 \mathrm{~mm}$ for boys and girls aged 6 to 7 (Cortese et al.). Moreover, a study performed by Sousa et al., in Brazil with an older group, 9-yearolds, determined the average maximum opening as $43.0 \mathrm{~mm}$ with no statistical differences between males and females. When compared, an increase in opening is seen as age increases without differences according to sex; this is similar to the results obtained.

A study carried out with a similar sample to those mentioned above, in Lebanon, shows an average of $45.8 \pm 0.6 \mathrm{~mm}$ in boys and girls with an average age of 9.1 (Abou-Atme et al.). Likewise, in India values of $46.0 \pm 0.4 \mathrm{~mm}$ (aged 6 to 8 ), $48.5 \pm 0.3 \mathrm{~mm}$ (aged 8 to 10), and 52.4 \pm 0.4 (aged 10 to 12) (Kumar et al.) are recorded; an increase in opening range coincides with an increase in age. Similarly, if we add this fact to the direct correlation between the ranges of opening and height, it is noted that the three are closely related to individual growth.

In relation to lateral movements, studies are disparate, but some obtain similar results to ours. Reicheneder et al. (2013) obtained similar values ranging between $3.3 \mathrm{~mm}$ to $13.8 \mathrm{~mm}$ on the right side and $4.2 \mathrm{~mm}$ to $13.4 \mathrm{~mm}$ on the left side. However, other studies found lower ranges of motion such as Sousa et al., who obtained an average of $8.3 \mathrm{~mm}$ on the right side and 8.1 on the left side; Bonjardim et al., measured averages of 6.6 and $6.9 \mathrm{~mm}$, respectively; and Cortese et al., observed $6.0 \mathrm{~mm}$ and $6.1 \mathrm{~mm}$, respectively.

There are few studies evaluating range of protrusion. Sousa et al., obtained average values of $7.0 \mathrm{~mm}$ in girls and $7.2 \mathrm{~mm}$ in boys; Bonjardim et al., observed an average of $5.7 \mathrm{~mm}$ in boys and $5.6 \mathrm{~mm}$ in girls; while Cortese et al., measured an average of $3.9 \mathrm{~mm}$ between boys and girls; these values are all lower than those obtained in this study.

Discrepancies among the reported results may be attributed to the fact that the changes produced by development at these ages do not provide for a single set of reference values, unlike what occurs with the information obtained from the adult population (Cortese et al.). Thus, it becomes necessary to consider the variables of age, sex, and height in the collection and analysis of MD values in children by determining study groups and subgroups (Sousa et al.; Kumar et al.).
Finally, the fact that there is a correlation between the different ranges of motion confirms the importance of evaluating all ranges when suspecting a disease in the TMJ or its associated structures. Exhibiting one or more altered values, added to patient health and symptomatology, may allow us an overall idea of mandibular dynamics, making us suspect a more specific disease, thus leading to more successful treatments.

\section{CONCLUSION}

The results of this study are of great importance, since in addition to providing specific data, they also provide evidence on the importance of evaluating all ranges of mandibular movement, and not only relating them to each other, but also to variables such as age and height. Thus, clinical work may be facilitated by understanding the specific mandibular dynamics of each patient and complementing this with suspicion of disease or the specific diagnosis of the pathologies affecting the mandibular system.

\section{ACKNOWLEDGMENTS}

We would like to thank CONICYT through National Doctoral Fellowship. CONICYT, PFCHA/ Doctorado Nacional/2015-21151352 for support this research.

ITURRIAGA, V.; BORNHARDT, T.; ARIAS, A.; ANTIAO, M.; ARAVENA, Y.; NAVARRO, P.; MANTEROLA, C. Rango de movimiento mandibular en pacientes pediátricos. Int. J. Odontostomat., 11(1):83-87, 2017.

RESUMEN: La valoración de los rangos del movimiento mandibular normal y sus respectivas variaciones constituyen una herramienta indispensable para la evaluación clínica del funcionamiento del sistema masticatorio y la búsqueda de alteraciones. El objetivo de este estudio fue medir los rangos de dinámica mandibular en movimientos de apertura bucal, protrusión y lateralidades en sujetos pediátricos de la ciudad de Temuco, Chile; y determinar su asociación con edad, sexo y estatura. Se realizó un estudio de corte transversal, en niños de 6-13 años atendidos en la Clínica Odontológica Docente Asistencial de la Universidad de La Frontera, Temuco-Chile. Se evaluaron los rangos de apertura bucal, protrusión, lateralidad derecha, lateralidad izquierda, edad, sexo y estatura de los sujetos, 
relacionandolos entre sí. Se evaluaron 54 sujetos $(44,4 \%$ mujeres), las niñas presentaron un promedio de apertura bucal de $51,9 \mathrm{~mm}$ y los niños de $54,8 \mathrm{~mm}$. El promedio de apertura bucal fue de $53,5 \mathrm{~mm}$; el de protrusión $11,8 \mathrm{~mm}$; el de lateralidad derecha $9,9 \mathrm{~mm}$; y el de lateralidad izquierda $10,3 \mathrm{~mm}$. Se encontró una diferencia estadísticamente significativa entre los distintos grupos de edad y el rango de apertura y lateralidad derecha, así como también una correlación débil a moderada entre el rango de apertura bucal y el de protrusión; el de protrusión y de lateralidad derecha; el de protrusión y lateralidad izquierda; el de lateralidad derecha e izquierda; estatura y apertura bucal; estatura y lateralidad derecha. Los resultados del presente estudio cobran gran importancia, ya que además de aportar con datos específicos aporta evidencia sobre la importancia de evaluar todos los rangos de movimiento mandibular, y no solo relacionarlos entre sí, sino también con variables como la edad y estatura. De este modo se facilitará el trabajo clínico de comprender la dinámica mandibular específica de cada paciente y complementarla con la sospecha de enfermedad o el diagnóstico específico de las patologías que afectan al sistema mandibular.

PALABRAS CLAVE: dinámica mandibular, articulación temporomandibular, trastornos temporomandibulares, rangos mandibulares, niños.

\section{REFERENCES}

Abou-Atme, Y. S.; Chedid, N.; Melis, M. \& Zawawi, K. H. clinical measurement of normal maximum mouth opening in children. Cranio, 26(3):1-6, 2008.

Bonjardim, L. R.; Pereira, L. J.; Gavião, M. B. D. \& Castelo, P. M. Mandibular movements in children with and without signs and symptoms of temporomandibular dysfunction. J. Appl. Oral Sci., 12(1):39-44, 2004.

Casanova-Rosado, J. F.; Medina-Solís, C. E.; Casanova-Rosado, A. J.; Vallejos-Sánchez, A. A.; Patiño-Marín, N.; Maupome, G. \& Gomez-Gomez, V. Clinical characterization of mouth opening among mexican adolescents and Young adults. J. Dent. Sci., 7(1):81-4, 2012.

Cortese, S. G.; Oliver, L. M. \& Biondi, A. M. Determination of range of mandibular movements in children without temporomandibular disorders. Cranio, 25(3):200-5, 2007.

Sousa, L. M.; Nagamine, H. M.; Chaves, T. C.; Grossi, D. B.; Regall, S. C. \& Oliviera, A. S. Evaluation of mandibular range of motion in Brazilian children and its correlation to age, height, weight and gender. Braz. Oral Res., 22(1):61-6, 2008.

Hirsch, C.; John, M. T.; Lautenschläger, C. \& List, T. Mandibular jaw movement capacity in 10-17-yr-old children and adolescents: normative values and the influence of gender, age, and temporomandibular disorders. Eur. J. Oral. Sci., 114(6):465-70, 2006.

Kumar, A.; Mehta, R.; Goel, M.; Dutta, S. \& Hooda, A. Maximal mouth opening in Indian children using a new method. J. Cranio. Max. Dis., 1(2):79-86, 2012.

Manns, A. Sistema Estomatognático Bases Biológicas y Correlaciones Clínicas. Santiago de Chile, Ripano, 2011.
Reicheneder, C.; Kardari, Z.; Proff, P.; Fanghaenel, J.; Faltermeier, A. \& Römer, P. Correlation of condylar kinematics in children with gender, facial type and weight. Ann. Anat., 195(3):243-7, 2013.

Von Elm, E.; Altman, D.; Egger, M.; Pocock, S.; Gotzsche, P. \& Vandenbroucke, J. Declaración de la Iniciativa STROBE (Strengthening the Reporting of Observational studies in Epidemiology): Directrices para la comunicación de estudios obsevacionales. Gac. Sanit., 22(2):144-50, 2008.

Correspondence to:

Veronica Iturriaga

Departamento de Odontología Integral del Adulto

Facultad de Odontología

Universidad de La Frontera.

Claro Solar 115

Temuco

CHILE

E-mail: veronica.iturriaga@ufrontera.cl

Received:19-12-2016

Accepted: 09-01-2017 